\title{
Classification of metal-resistant bacteria from industrial biotopes as Ralstonia campinensis sp. nov., Ralstonia metallidurans sp. nov. and Ralstonia basilensis Steinle et al. 1998 emend.
}

\author{
1 Laboratorium voor \\ Microbiologie, \\ Universiteit Gent, K. L. \\ Ledeganckstraat 35, \\ B-9000 Gent, Belgium \\ 2 BCCM/LMG Bacteria \\ Collection, Laboratorium \\ voor Microbiologie, \\ Universiteit Gent, K. L. \\ Ledeganckstraat 35, \\ B-9000 Gent, Belgium \\ 3,4 Environmental \\ Technology, Vlaamse \\ Instelling voor \\ Technologisch Onderzoek \\ (VITO) ${ }^{3}$ and Laboratory \\ for Microbiology, \\ Radioactive Waste \& \\ Clean-up Division, \\ SCK/CEN (Center of \\ Studies for Nuclear \\ Energy) ${ }^{4}$, Boeretang 200, \\ B-2400 Mol, Belgium
}

\author{
Johan Goris, ${ }^{1}$ Paul De Vos, ${ }^{1}$ Tom Coenye, ${ }^{1}$ Bart Hoste, ${ }^{2}$ Danielle Janssens, ${ }^{2}$ \\ Hassan Brim, ${ }^{3}$ Ludo Diels, ${ }^{3}$ Max Mergeay, ${ }^{3,4}$ Karel Kersters ${ }^{1,2}$ \\ and Peter Vandamme ${ }^{1}$
}

Author for correspondence: Johan Goris. Tel: +329264 51 01. Fax: +3292645346. e-mail: johan.goris@rug.ac.be

Thirty-one heavy-metal-resistant bacteria isolated from industrial biotopes were subjected to polyphasic characterization, including 16S rDNA sequence analysis, DNA-DNA hybridizations, biochemical tests, whole-cell protein and fatty-acid analyses. All strains were shown to belong to the Ralstonia branch of the $\beta$-Proteobacteria. Whole-cell protein profiles and DNA-DNA hybridizations revealed two clearly distinct groups, showing low similarity to known Ralstonia species. These two groups, of 8 and 17 isolates, were assigned to two new species, for which the names Ralstonia campinensis sp. nov. and Ralstonia metallidurans sp. nov. are proposed. The type strains are WS2 ${ }^{\mathrm{T}}$ ( = LMG 19282 ${ }^{\mathrm{T}}=$ CCUG 44526 $^{\mathrm{T}}$ ) and CH34 ${ }^{\mathrm{T}}$ ( = LMG 1195 ${ }^{\mathrm{T}}=$ DSM 2839 $^{\mathrm{T}}$ ), respectively. Six isolates were allocated to Ralstonia basilensis, which presently contains only the type strain; an emendation of the latter species description is therefore proposed.

Keywords: Ralstonia, metal-resistance, taxonomy, industrial biotopes

\section{INTRODUCTION}

Metal resistance has been reported for a number of Gram-negative bacteria belonging to the Ralstonia lineage of the $\beta$-Proteobacteria (Diels \& Mergeay, 1990; Mergeay et al., 1985; Schmidt et al., 1991; Schmidt \& Schlegel, 1994). Resistance to $\mathrm{Cd}^{2+}, \mathrm{Zn}^{2+}$ and $\mathrm{Co}^{2+}$ has been shown to be located on a $c z c$ operon of the plasmid pMOL30 $(240 \mathrm{~kb})$, while $\mathrm{Co}^{2+}$ combined with $\mathrm{Ni}^{2+}$ resistance is located on the $\mathrm{cnr}$ operon of the plasmid pMOL28 (163 kb) (Liesegang et al., 1993; Mergeay et al., 1985; Nies et al., 1987; Siddiqui et al., 1989). Other plasmid-borne resistances to metals include resistance to copper (cop), lead ( $p b r)$ and mercury (mer) on pMOL30 and resistance to chromate (chr) and mercury on pMOL28 (for a review see Mergeay, 2000). Hybridization with a $c z c$ gene

The EMBL accession numbers for the 16S rRNA gene sequences of $R$. campinensis WS2 ${ }^{\top}$ and $R$. basilensis ER 121 and DSM $11853^{\top}$ are AF312020, AF312021 and AF312022, respectively. probe showed the spread of the former resistance types over a variety of closely related taxa (Brim et al., 1999).

The application of metal-resistant bacteria in bioremediation processes offers attractive perspectives for biomonitoring (via biosensors), treatment of wastewater and the recycling of polluted soils (Collard et al., 1994; Diels et al., 1995). In the case of the Ralstonia strains mentioned above, knowledge of their exact taxonomic position is of the utmost importance. Indeed, in addition to organisms that can be used for bioremediation of polluted soils, the genus Ralstonia also contains an important plant pathogen (Ralstonia solanacearum; Hayward, 1991) and several opportunistic human pathogens such as Ralstonia pickettii (Ralston et al., 1973), Ralstonia mannitolytica (De Baere et al., 2001), Ralstonia gilardii (Coenye et al., 1999) and Ralstonia paucula (Vandamme et al., 1999). Ralstonia strains with potential large-scale applications for bioremediation should obviously be distinct from (opportunistic) pathogens of humans and plants. Recent taxonomic studies describing novel Ralstonia species highlight not only the unsuspected 


\section{Table 1. List of strains studied}

Culture collections are abbreviated as: API, Appareils et Procédés d'Identification, Montalieu-Vercieu, France; ATCC, American Type Culture Collection, Manassas, VA, USA; CCUG, Culture Collection, University of Göteborg, Sweden; CDC, Center for Disease Control, Atlanta, GA, USA; CIP, Collection de l'Institut Pasteur, Paris, France; DSM, Deutsche Sammlung von Mikroorganismen und Zellkulturen, Braunschweig, Germany; IAM, Institute of Applied Microbiology, University of Tokyo, Japan; LMG, BCCM/LMG Bacteria Collection, Laboratorium voor Microbiologie, Universiteit Gent, Belgium; NCIB, National Collection of Industrial Bacteria, Aberdeen, UK.

\begin{tabular}{|c|c|c|}
\hline Strain number as received & Other strain designation(s) & Source \\
\hline \multicolumn{3}{|l|}{ Ralstonia campinensis } \\
\hline DS185 & LMG 19284 & Zinc desert, Lommel, Belgium \\
\hline LH103 & LMG 19285 & Non-ferrous industry, Tienen, Belgium \\
\hline LH104 & & Non-ferrous industry, Tienen, Belgium \\
\hline LH105 & LMG 19283 & Non-ferrous industry, Tienen, Belgium \\
\hline \multicolumn{3}{|r|}{ 然 } \\
\hline $\mathrm{WS} 2^{\mathrm{T}}$ & LMG $19282^{\mathrm{T}}$, CCUG $44526^{\mathrm{T}}$ & Zinc desert, Lommel, Belgium \\
\hline \multicolumn{3}{|r|}{ - } \\
\hline WS5 & & Zinc desert, Lommel, Belgium \\
\hline \multicolumn{3}{|l|}{ Ralstonia eutropha } \\
\hline ATCC $17697^{\mathrm{T}}$ & LMG $1199^{\mathrm{T}}, \mathrm{TF}^{\mathrm{T}}{ }^{\mathrm{T}}$ & Soil (USA, 1957) \\
\hline ATCC 17698 & LMG 1200 & Garden-pond sludge, Germany \\
\hline ATCC 17699 & LMG 1201, H16 & Sludge, Weende-Quelle, Göttingen, Germany \\
\hline ATCC 17700 & LMG $1202, \mathrm{H} 20$ & Soil, USA \\
\hline ATCC 17702 & LMG 1203 & Soil \\
\hline ATCC 17704 & LMG 1204 & Soil \\
\hline ATCC 17705 & LMG 1205 & Soil \\
\hline ATCC 17706 & LMG 1206 & \\
\hline ATCC 17709 & LMG 1209 & Soil, USA \\
\hline ATCC 17710 & LMG 1210 & USA \\
\hline ATCC 25207 & LMG 1211 & \\
\hline ATCC 33178 & LMG 1190 & Paddy-field soil, Japan \\
\hline $\mathrm{N} 9 \mathrm{~A}$ & LMG 1196 & \\
\hline \multicolumn{3}{|l|}{ Ralstonia basilensis } \\
\hline DSM $11853^{\mathrm{T}}$ & LMG $18990^{\mathrm{T}}$, LMG $19474^{\mathrm{T}}, \mathrm{RK} 1^{\mathrm{T}}$ & Freshwater-pond sediment, Amponville, France \\
\hline ER8 & LMG 19287 & Non-ferrous industry, Overpelt, Belgium \\
\hline ER107 & & Non-ferrous industry, Overpelt, Belgium \\
\hline ER121 & & Non-ferrous industry, Overpelt, Belgium \\
\hline ER122 & LMG 19286 & Non-ferrous industry, Overpelt, Belgium \\
\hline KS1 & LMG 19289 & Zinc desert, Lommel, Belgium \\
\hline SV884 & LMG 19288 & \\
\hline \multicolumn{3}{|l|}{ Ralstonia metallidurans } \\
\hline $31 \mathrm{~A}$ & LMG 19293 & Metal factory, Holzminden, Germany \\
\hline $\mathrm{AB} 2$ & & Mine area, Kipushi, Congo \\
\hline AS2 & LMG 19295 & Mine area, Likasi-Sud, Congo \\
\hline AS167 & LMG 19291 & Mine area, Likasi-Sud, Congo \\
\hline AS168 & & Mine area, Likasi-Sud, Congo \\
\hline $\mathrm{CH} 34^{\mathrm{T}}$ & LMG $1195^{\mathrm{T}}$, CCUG $38400^{\mathrm{T}}$, DSM $2839^{\mathrm{T}}$ & Wastewater, 'Métallurgie de Prayon' zinc factory, Liège, Belgium \\
\hline $\mathrm{CH} 42$ & & Polluted sediments, 'Métallurgie de Prayon' zinc factory, Liège, Belgium \\
\hline $\mathrm{CH} 45$ & & Polluted sediments, 'Métallurgie de Prayon' zinc factory, Liège, Belgium \\
\hline $\mathrm{CH} 79$ & LMG 19296 & Polluted sediments, 'Métallurgie de Prayon' zinc factory, Liège, Belgium \\
\hline Sh2-1 & LMG 19294 & Mine area, Shituru, Congo \\
\hline SV661 & LMG 19290 & Non-ferrous industry, Beerse, Belgium \\
\hline VA1 & & Mine area, Likasi-Sud, Congo \\
\hline VA2 & & Mine area, Likasi-Sud, Congo \\
\hline VA3 & & Mine area, Likasi-Sud, Congo \\
\hline VA7 & LMG 19297 & Mine area, Likasi-Sud, Congo \\
\hline VA10 & LMG 19292 & Mine area, Likasi-Sud, Congo \\
\hline VA11 & & Mine area, Likasi-Sud, Congo \\
\hline Ralstonia pickettii CCUG $3318^{\mathrm{T}}$ & LMG $5942^{\mathrm{T}}$, ATCC $27511^{\mathrm{T}}$ & Patient after tracheotomy, Los Angeles, USA \\
\hline Ralstonia solanacearum $\mathrm{NCPPB} 325^{\mathrm{T}}$ & LMG $2299^{\mathrm{T}}$, ATCC $11696^{\mathrm{T}}$ & Lycopersicon esculentum (tomato), USA \\
\hline Ralstonia gilardii API 141-2-84 & LMG $5886^{\mathrm{T}}$ & Whirlpool \\
\hline Ralstonia paucula $\mathrm{CDC}$ E $6793^{\mathrm{T}}$ & LMG $3244^{\mathrm{T}}$ & Human, respiratory tract, USA \\
\hline Ralstonia paucula CIP 62.31 & LMG 3413, CCUG 13723 & \\
\hline Ralstonia oxalatica $\mathrm{Ox}^{\mathrm{T}}$ & LMG $2235^{\mathrm{T}}$, DSM $1105^{\mathrm{T}}$ & Indian earthworm \\
\hline Ralstonia mannitolytica $\mathrm{NCIB} 10805^{\mathrm{T}}$ & LMG $6866^{\mathrm{T}}$ & Hospital outbreak, St Thomas' Hospital, London, UK \\
\hline Ralstonia sp. ATCC 17707 & LMG 1207 & Soil \\
\hline Ralstonia sp. JMP134 & LMG 1197 & Agricultural soil, Australia \\
\hline
\end{tabular}

biodiversity of the genus but also its weak and incomplete internal classification. The present report deals with the polyphasic classification of 31 metalresistant strains, isolated from diverse industrial locations. Six strains could be allocated to Ralstonia basilensis, while two groups, of 8 and 17 strains, respectively, are representatives of new Ralstonia species, for which we propose the names Ralstonia campinensis sp. nov. and Ralstonia metallidurans sp. nov. 


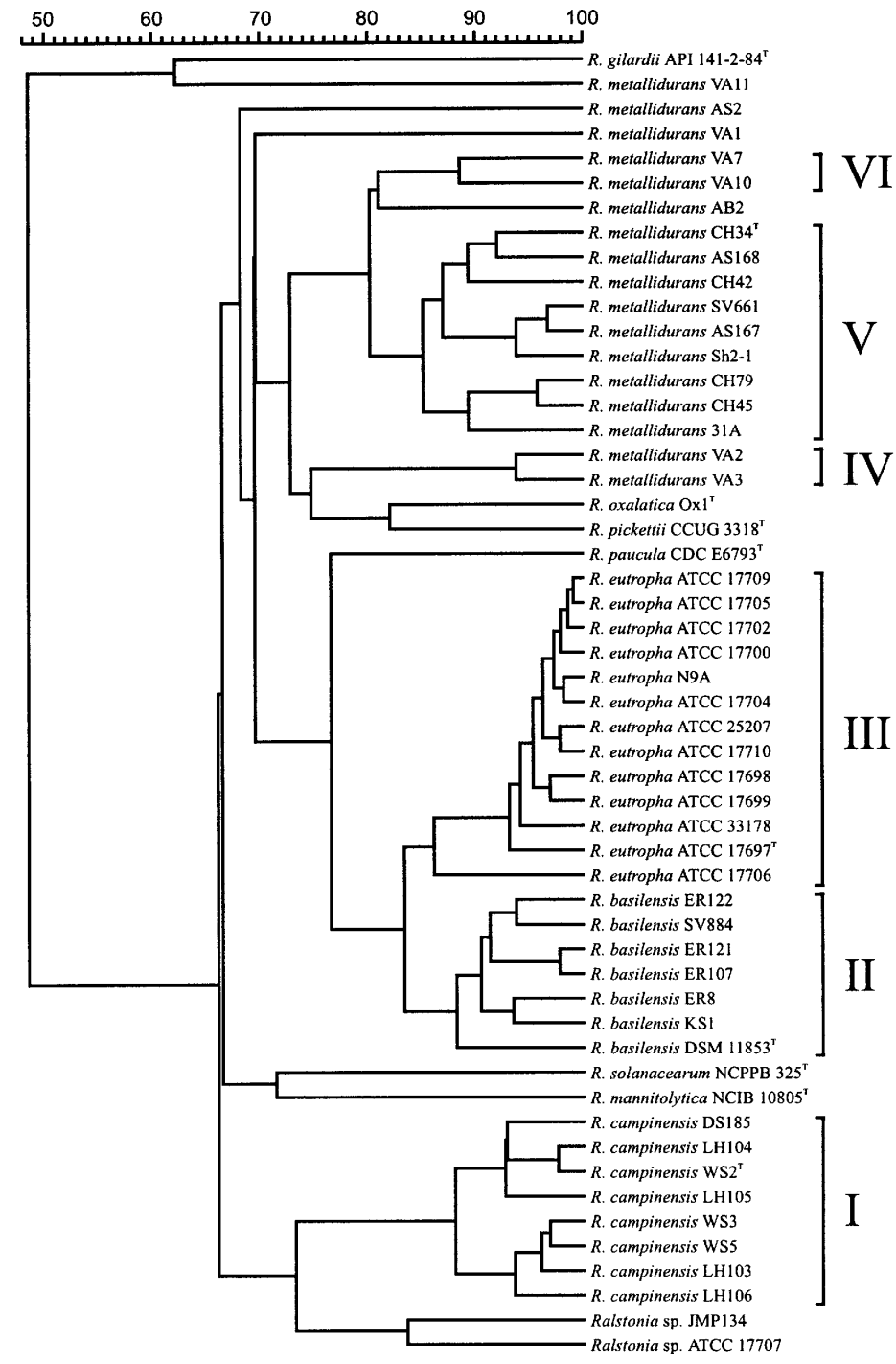

Fig. 1. Dendrogram based on UPGMA clustering of SDS-PAGE analyses of wholecell proteins of Ralstonia isolates. The zones used for numerical analysis were between 18.6 and $32.1 \mathrm{kDa}$ and 38 and $107 \mathrm{kDa}$. Similarities are expressed as percentages.

\section{METHODS}

Bacterial strains and growth conditions. Bacterial strains used in this study are listed in Table 1. After being checked for purity, subcultures of all strains were maintained on slants of Tryptic soy agar [TSA; Trypticase soy broth (Becton \& Dickinson) supplemented with 15 g Bacto Agar (Difco) $1^{-1}$ ] in the refrigerator and lyophilized for long-term storage.

PAGE of whole-cell proteins. Cells were grown for $48 \mathrm{~h}$ on TSA at $37^{\circ} \mathrm{C}$. SDS protein extracts were prepared and separated by electrophoresis as described by Pot et al. (1994). The collected data were interpreted as described by Vauterin \& Vauterin (1992), using the GELCOMPAR 4.2 software (Applied Maths). Similarity between all pairs of electrophoresis patterns was calculated by Pearson's product-moment correlation coefficient, expressed as a percentage.

DNA-DNA hybridizations. DNA was prepared by the method of Marmur (1961), as modified by Vandamme et al. (1992), or by a modification of the protocol of Pitcher et al. (1989). Briefly, 500-750 mg cell mass was harvested from agar surfaces, washed with $15 \mathrm{ml}$ RS buffer $(0 \cdot 15 \mathrm{M} \mathrm{NaCl}, 0 \cdot 01 \mathrm{M}$ EDTA; $\mathrm{pH} 8.0$ ), centrifuged and resuspended in $3 \mathrm{ml}$ TE buffer $(1.21 \mathrm{~g}$ Tris/HCl, $2 \mathrm{ml} \mathrm{0.5} \mathrm{M} \mathrm{EDTA;} \mathrm{pH} 8.0$ in 11 MilliQ water). Fifteen $\mathrm{ml}$ GES reagent (600 g guanidinium thiocyanate, $200 \mathrm{ml} \mathrm{0.5} \mathrm{M} \mathrm{EDTA;} \mathrm{pH} 8.0,10 \mathrm{~g}$ Sarcosyl in 11 MilliQ water) was added and the suspension was mixed gently until cell lysis occurred and then left on ice for $15 \mathrm{~min}$. Ammonium acetate $(7.5 \mathrm{ml}, 7.5 \mathrm{M})$ was added and the suspension was mixed again and left on ice for $15 \mathrm{~min}$. Ten $\mathrm{ml}$ chloroform/isoamyl alcohol $(24: 1)$ was added and the suspension was mixed vigorously. After $20 \mathrm{~min}$ of centrifugation at $17000 \mathrm{~g}$, the upper phase was transferred to a disposable plastic beaker and 0.54 vols 2-propanol were added. The DNA was spooled onto a glass rod, washed in a series of ethanol solutions $(70,80$ and $90 \% \mathrm{v} / \mathrm{v})$, air-dried and dissolved overnight in $5 \mathrm{ml}$ TE buffer. When the DNA was dissolved completely, $25 \mu \mathrm{l}$ RNase solution $\left(2 \mathrm{mg} \mathrm{ml}^{-1}\right.$ ) was added and incubated for $1 \mathrm{~h}$ at $37^{\circ} \mathrm{C}$. After RNase treatment, $625 \mu \mathrm{l}$ acetate/EDTA (3 M sodium acetate, $1 \mathrm{mM}$ EDTA; pH 7.0) was added and the chloroform extraction repeated. The supernatant was again transferred to a disposable plastic beaker and DNA was precipitated with 2 vols ethanol, spooled onto a glass rod, washed in an 


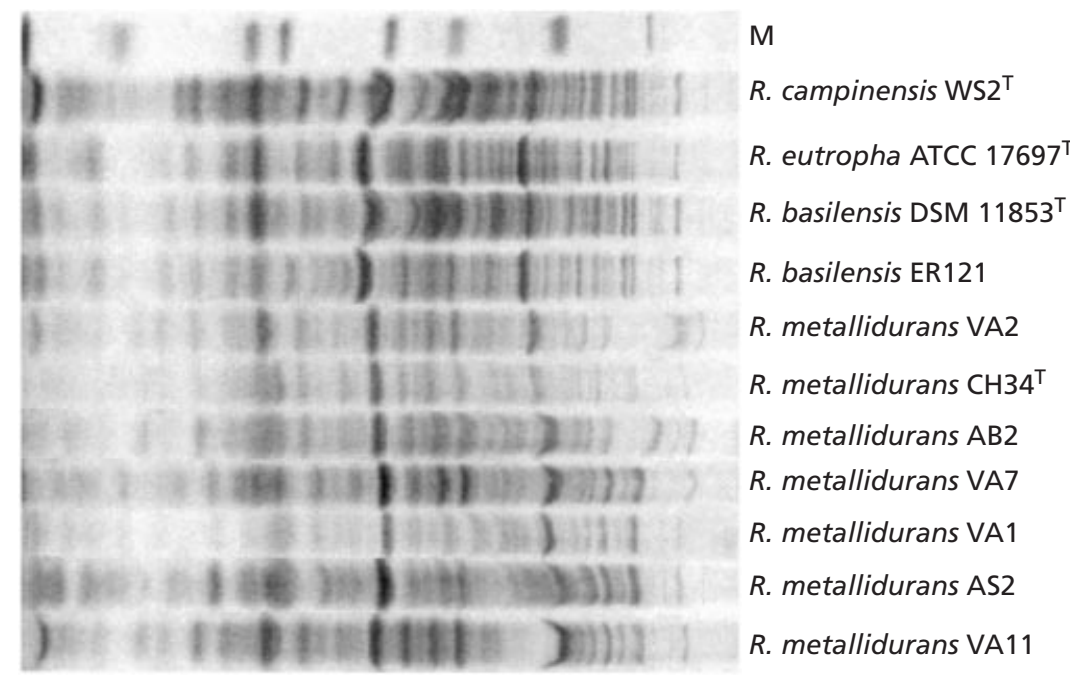

\begin{abstract}
Fig. 2. Photograph of whole-cell proteins patterns of Ralstonia strains illustrating the presence of reproducible strain-specific distortions. The molecular mass markers (M) used were (from left to right) lysozyme $(14.5 \mathrm{kDa})$, trypsin inhibitor $(20.1 \mathrm{kDa})$, trypsinogen $(24 \mathrm{kDa})$, carbonic anhydrase $(29 \mathrm{kDa}), \quad$ glyceraldehyde-3-phosphate dehydrogenase (36 kDa), egg albumin (45 kDa), bovine albumin $(66 \mathrm{kDa})$ and $\beta$-galactosidase (116 kDa).
\end{abstract}

ethanol series and air-dried. Finally, the DNA was dissolved in $1 \mathrm{ml} 0.1 \times \mathrm{SSC}(1 \times \mathrm{SSC}$ contains $0.15 \mathrm{M} \mathrm{NaCl}$ and $0.015 \mathrm{M}$ sodium citrate).

DNA-DNA hybridizations were performed either by the initial renaturation rate method of De Ley et al. (1970) or with the microplate method as described by Ezaki et al. (1989). In the latter case, an HTS7000 Bio Assay Reader (Perkin Elmer) was used for fluorescence measurements in white MaxiSorp (Nunc) microplates. The hybridization conditions were respectively $81^{\circ} \mathrm{C}$ in $2 \times \mathrm{SSC}$ and $50^{\circ} \mathrm{C}$ in $2 \times \mathrm{SSC}$ with $50 \%(\mathrm{v} / \mathrm{v})$ formamide for the initial renaturation method and the microplate method. Results obtained by the two methods were shown previously to correlate very well (Goris et al., 1998).

DNA base compositions. DNA was degraded enzymically into nucleosides as described by Mesbah et al. (1989). The analysis parameters were as reported in Logan et al. (2000).

16S rDNA sequencing. 16S rDNA sequencing was performed using an Applied Biosystems 377 DNA sequencer as described by Coenye et al. (1999). Partial sequences were assembled using the program Auto Assembler (Applied Biosystems) and phylogenetic analysis was performed using the BioNumerics 1.5 software package (Applied Maths).

GC analysis of methylated fatty acids. Cells were grown for $24 \mathrm{~h}$ on TSA at $28^{\circ} \mathrm{C}$ and fatty acid methyl esters were extracted, prepared, separated and identified by using the Microbial Identification System (Microbial ID) as described before (Vauterin et al., 1991).

Phenotypic tests. Classical phenotypic tests were performed as described previously (De Vos et al., 1985). API $20 \mathrm{NE}$ and API ZYM (bioMérieux) were utilized according to the protocol supplied by the manufacturer.

\section{RESULTS}

\section{PAGE of whole-cell proteins}

The result of a numerical analysis based on whole-cell protein profiles is shown in Fig. 1. A zone corresponding to molecular masses between $32 \cdot 1$ and
$38 \mathrm{kDa}$ was omitted from the analysis. This zone comprised a distorted band in the profile of some cluster I (R. campinensis) strains, e.g. WS $2^{\mathrm{T}}$ (see Fig. 2). Six (I-VI) major clusters and 12 strains holding a distinct position in the dendrogram (Fig. 1) were differentiated above a correlation level of $85 \%$. The Ralstonia eutropha reference strains formed a single homogeneous cluster (cluster III), grouping above $86.1 \%$ similarity. The type strains of $R$. pickettii, $R$. gilardii, $R$. paucula, $R$. solanacearum, $R$. mannitolytica and Ralstonia oxalatica (Şahin et al., 2000) occupied distinct positions. Six isolates grouped together with the type strain of $R$. basilensis in cluster II, above $88.1 \%$ similarity. The other metal-resistant isolates were found scattered over clusters IV, V and VI, whereas isolates AB2, AS2, VA1 and VA11 occupied separate positions in the dendrogram. The protein patterns of the latter strains were visually very similar, in apparent contradiction to their locations in the dendrogram. Reproducible protein band distortions were indeed observed above the $116 \mathrm{kDa}$ region for the cluster IV strains and around the $60 \mathrm{kDa}$ region for strains VA10 and VA7 (forming cluster VI), as well as for strains AB2, AS2, VA1 and VA11 (Fig. 2). Little or no band distortion was observed in the protein patterns of the isolates grouping above $85 \%$ correlation in cluster V (e.g. the pattern of $R$. metallidurans $\mathrm{CH} 34^{\mathrm{T}}$ in Fig. 2). The presence of reproducible strain-specific distortions has been described within other species of Ralstonia (Vandamme et al., 1999). DNA-DNA hybridization experiments confirmed that these distortions represent intra-species variability and not inter-species variability (see below; Vandamme et al., 1999).

Ralstonia sp. JMP134 and ATCC 17707 occupied separate positions in the dendrogram. Both strains were received originally as $R$. eutropha but, since their whole-cell protein profiles differed clearly from those of the other $R$. eutropha strains (cluster III), we 
Table 2. DNA-DNA reassociation values and nucleotide compositions of $R$. campinensis, $R$. metallidurans, $R$. basilensis and Ralstonia reference strains

\begin{tabular}{|c|c|c|c|c|c|c|c|c|c|c|c|c|c|c|c|c|}
\hline \multirow{2}{*}{ Strain } & \multirow{2}{*}{$\begin{array}{l}\text { PAGE } \\
\text { cluster }\end{array}$} & \multirow{2}{*}{$\begin{array}{c}\mathbf{G}+\mathbf{C} \text { content } \\
\quad(\mathrm{mol} \%)\end{array}$} & \multicolumn{14}{|c|}{ DNA-DNA reassociation (\%) with:* } \\
\hline & & & 1 & 2 & 3 & 4 & 5 & 6 & 7 & 8 & 9 & 10 & 11 & 12 & 13 & 14 \\
\hline 1. R. campinensis $\mathrm{WS} 2^{\mathrm{T}}$ & I & 66.6 & 100 & & & & & & & & & & & & & \\
\hline 2. R. campinensis $\mathrm{LH} 103$ & I & $66 \cdot 8$ & $100^{a}$ & 100 & & & & & & & & & & & & \\
\hline 3. R. paucula CDC E6793 ${ }^{\mathrm{T}}$ & - & $64 \cdot 2$ & $31^{b}$ & & 100 & & & & & & & & & & & \\
\hline 4. R. paucula CIP 62.31 & - & $65 \dagger$ & $25^{a}$ & & $82 \dagger$ & 100 & & & & & & & & & & \\
\hline 5. R. basilensis DSM $11853^{\mathrm{T}}$ & II & $65 \cdot 0$ & $18^{b}$ & & $17^{b}$ & & 100 & & & & & & & & & \\
\hline 6. R. basilensis ER8 & II & $65 \cdot 5$ & $14^{a}, 22^{b}$ & & $20^{a}, 19^{b}$ & & $78^{b}$ & 100 & & & & & & & & \\
\hline 7. R. basilensis ER 121 & II & $65 \cdot 4$ & & $32^{b}$ & $3^{a}$ & & & $61^{\alpha}$ & 100 & & & & & & & \\
\hline 8. R. metallidurans VA7 & VI & ND & & & & $29^{a}$ & & & & 100 & & & & & & \\
\hline 9. $R$. metallidurans $\mathrm{CH} 79$ & $\mathrm{v}$ & $63 \cdot 9$ & & $29^{a}$ & $31^{a}$ & $37^{b}$ & & & & $83^{a}$ & 100 & & & & & \\
\hline 10. R. metallidurans $\mathrm{CH} 34^{\mathrm{T}}$ & $\mathrm{v}$ & $63 \cdot 7$ & $26^{b}$ & $37^{b}$ & $35^{b}$ & $39^{b}$ & $16^{b}$ & $17^{a}, 16^{b}$ & $2^{a}, 25^{b}$ & & $84^{a}, 88^{b}$ & 100 & & & & \\
\hline 11. R. eutropha ATCC $17697^{\mathrm{T}}$ & - & $66 \cdot 6$ & $18^{a}, 26^{b}$ & $41^{b}$ & $21^{b}$ & $24 \dagger$ & $20^{b}$ & $22^{a}, 25^{b}$ & $8^{a}, 37^{b}$ & $0^{a}$ & & $28^{b}$ & 100 & & & \\
\hline 12. R. solanacearum $\mathrm{NCPPB} 325^{\mathrm{T}}$ & - & $67 \cdot 0$ & $24^{a}, 11^{b}$ & & $16 \dagger, 10^{b}$ & $19^{a}$ & $8^{b}$ & $11^{b}$ & $17^{a}$ & & $18^{a}$ & $1^{a}, 10^{b}$ & $1^{a}, 13^{b}$ & 100 & & \\
\hline 13. R. gilardii API 141-02-84 & - & $68 \cdot 3 \ddagger$ & & $26^{b}$ & $21 \dagger$ & & & & $22^{b}$ & & & $20^{b}$ & $0 \ddagger, 40^{b}$ & & 100 & \\
\hline 14. R. pickettii CCUG $3318^{\mathrm{T}}$ & - & 63.8 & $20^{a}$ & $21^{a}, 18^{b}$ & $13 \dagger$ & & & $20^{\alpha}$ & $5^{a}, 17^{b}$ & & & $3^{a}, 20^{b}$ & $35^{a}, 25^{b}$ & $32^{a}$ & $21^{b}$ & 100 \\
\hline
\end{tabular}

* Determined by: $a$, initial renaturation rate method (values are means from at least two independent reactions); $b$, microplate method (values are means from at least two reciprocal reactions).

$\uparrow$ Data from Vandamme et al. (1999).

\$ Data from Coenye et al. (1999).

ND, Not determined.

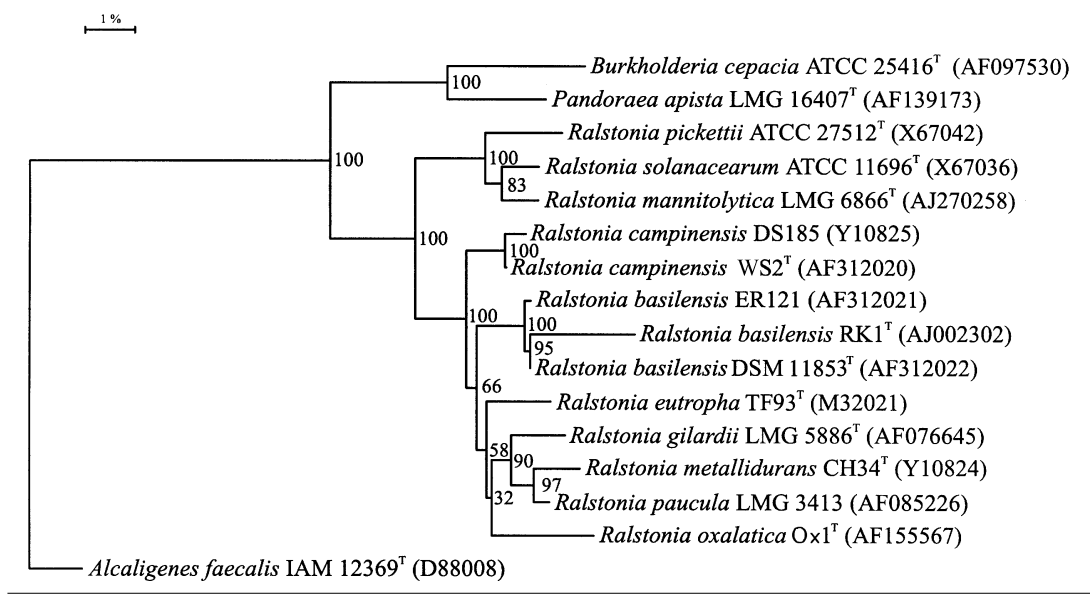

Fig. 3. Neighbour-joining phylogenetic tree of all described Ralstonia species, based on $16 S$ rDNA sequence comparisons. Bootstrap values obtained with 500 repetitions are indicated as percentages at all branches. The $16 \mathrm{~S}$ rDNA sequences of Alcaligenes faecalis, Burkholderia cepacia and Pandoraea apista were included as outgroups.

consider them here as 'Ralstonia eutropha-like' organisms pending further taxonomic analyses.

\section{DNA-DNA hybridizations and DNA base compositions}

Strains representing the protein electrophoretic types were hybridized with type strains of the valid Ralstonia species. DNA-DNA reassociation values and nucleotide compositions are shown in Table 2. The type strain of $R$. basilensis showed high DNA reassociation values $(61-78 \%)$ with strains ER121 and ER8. These three strains are representatives of protein electrophoretic cluster II and showed only low to intermediate DNA reassociation values $(2-37 \%)$ with representatives of other Ralstonia species. Hybridization values between $R$. campinensis WS2 ${ }^{\mathrm{T}}$ and LH103 (represen- tatives of protein electrophoretic cluster I) were high $(100 \%)$, while low to intermediate DNA relatedness $(11-41 \%)$ was found between the above-mentioned $R$. campinensis strains and representatives of the other Ralstonia species. The metal-resistant strains $\mathrm{CH} 34^{\mathrm{T}}$, CH79 and VA7, representing protein electrophoretic clusters V and VI, formed a homogeneous DNAreassociation group $(83-88 \% ; R$. metallidurans $)$, showing low to intermediate DNA relatedness $(0-$ $39 \%$ ) to representatives of other Ralstonia species. The high DNA relatedness observed between $R$. metallidurans strains from clusters V and VI confirmed that the protein electrophoretic differences detected reveal intra-species and not inter-species diversity.

The nucleotide compositions presented in Table 2 are in good agreement with those reported for the 
Table 3. Comparative fatty acid patterns of Ralstonia species

Species are identified as: $1, R$. campinensis (8 strains);2, R. basilensis (8 strains); 3, R. metallidurans (16 strains); 4, R. eutropha

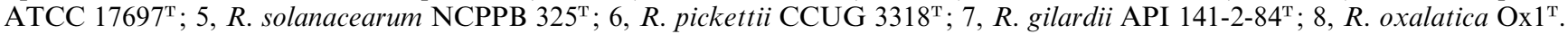
TR, Fatty acid content below $1 \%$. Summed feature 2 comprises 14:0 3OH, 16:1 iso I, an unidentified fatty acid with equivalent chain-length value of 10.928, 12:0 ALDE or any combination of these fatty acids. Summed feature 3 comprises $16: 1 \omega 7 c, 15$ iso $2 \mathrm{OH}, 15: 0$ iso $2 \mathrm{OH}, 16: 1 \omega 7 c$ or any combination of these fatty acids.

\begin{tabular}{|c|c|c|c|c|c|c|c|c|}
\hline Fatty acid & 1 & 2 & 3 & 4 & 5 & 6 & 7 & 8 \\
\hline $12: 0$ & - & - & - & - & - & TR & TR & - \\
\hline $14: 0$ & $5 \cdot 0 \pm 0 \cdot 3$ & $4 \cdot 5 \pm 0 \cdot 1$ & $4 \cdot 4 \pm 0 \cdot 2$ & $2 \cdot 9$ & $4 \cdot 2$ & $4 \cdot 5$ & $4 \cdot 1$ & $2 \cdot 6$ \\
\hline $15: 0$ & - & - & - & TR & TR & $\mathrm{TR}$ & TR & $\mathrm{TR}$ \\
\hline $15: 0$ iso & - & - & - & - & - & $\mathrm{TR}$ & - & - \\
\hline $16: 0$ & $24 \cdot 6 \pm 1 \cdot 7$ & $20 \cdot 6 \pm 0 \cdot 9$ & $20 \cdot 9 \pm 1 \cdot 4$ & $20 \cdot 6$ & $22 \cdot 1$ & $25 \cdot 4$ & $17 \cdot 7$ & $16 \cdot 8$ \\
\hline $16: 0$ iso & - & - & TR & - & - & - & - & - \\
\hline $17: 0$ & - & - & - & TR & $1 \cdot 5$ & TR & TR & $\mathrm{TR}$ \\
\hline 17:0 cyclo & $6 \cdot 1 \pm 3 \cdot 5$ & $1 \cdot 3 \pm 0 \cdot 9$ & $3 \cdot 2 \pm 2 \cdot 1$ & $2 \cdot 0$ & $2 \cdot 1$ & $\mathrm{TR}$ & $1 \cdot 2$ & $2 \cdot 0$ \\
\hline $18: 0$ & $1 \cdot 5 \pm 4 \cdot 9$ & TR & TR & $\mathrm{TR}$ & $\mathrm{TR}$ & TR & $\mathrm{TR}$ & $\mathrm{TR}$ \\
\hline $15: 1 \omega 6 c$ & - & - & - & TR & $\mathrm{TR}$ & TR & - & $\mathrm{TR}$ \\
\hline $16: 1 \omega 5 c$ & - & - & - & $\mathrm{TR}$ & - & TR & - & $\mathrm{TR}$ \\
\hline $18: 1 \omega 7 c$ & $19 \cdot 5 \pm 1 \cdot 8$ & $24 \cdot 7 \pm 1 \cdot 3$ & $19 \cdot 8 \pm 2 \cdot 9$ & $18 \cdot 5$ & $19 \cdot 2$ & $20 \cdot 0$ & $36 \cdot 4$ & $20 \cdot 7$ \\
\hline $19: 0$ cyclo $\omega 8 c$ & TR & - & $\mathrm{TR}$ & - & - & - & $\mathrm{TR}$ & - \\
\hline $14: 02 \mathrm{OH}$ & $2 \cdot 1 \pm 0 \cdot 2$ & - & $\mathrm{TR}$ & $3 \cdot 2$ & - & TR & $\mathrm{TR}$ & $3 \cdot 8$ \\
\hline $16: 12 \mathrm{OH}$ & $\mathrm{TR}$ & $1 \cdot 8 \pm 0 \cdot 8$ & $\mathrm{TR}$ & $\mathrm{TR}$ & $1 \cdot 3$ & $1 \cdot 2$ & - & - \\
\hline $16: 02 \mathrm{OH}$ & TR & $\mathrm{TR}$ & $3 \cdot 3 \pm 0 \cdot 4$ & - & $\mathrm{TR}$ & TR & $\mathrm{TR}$ & - \\
\hline $16: 03 \mathrm{OH}$ & - & - & - & TR & - & - & - & - \\
\hline $18: 12 \mathrm{OH}$ & $2 \cdot 7 \pm 0 \cdot 5$ & $4 \cdot 8 \pm 0 \cdot 4$ & $1 \cdot 4 \pm 0 \cdot 4$ & TR & $4 \cdot 0$ & $3 \cdot 3$ & $2 \cdot 0$ & - \\
\hline Summed feature 2 & $8 \cdot 9 \pm 1 \cdot 4$ & $9 \cdot 0 \pm 0 \cdot 5$ & $11 \cdot 3 \pm 2 \cdot 5$ & $13 \cdot 7$ & $9 \cdot 8$ & $7 \cdot 7$ & $8 \cdot 1$ & $15 \cdot 4$ \\
\hline Summed feature 3 & $28 \cdot 4 \pm 4 \cdot 0$ & $32 \cdot 9 \pm 1 \cdot 4$ & $34 \cdot 2 \pm 2 \cdot 9$ & $36 \cdot 5$ & $32 \cdot 7$ & $34 \cdot 2$ & $27 \cdot 8$ & $36 \cdot 6$ \\
\hline
\end{tabular}

genus and are not in contradiction with the grouping based on whole-cell protein profiles and DNA-DNA hybridizations.

\section{S rDNA sequencing}

A phylogenetic tree including all Ralstonia species is given in Fig. 3. Compared with known representatives of validly described Ralstonia species, the 16S rRNA genes of $R$. campinensis WS2 $2^{\mathrm{T}}$ and $R$. metallidurans $\mathrm{CH} 34^{\mathrm{T}}$ showed the highest sequence similarity $(98 \cdot 2$ and $98.8 \%$ ) to the $16 \mathrm{~S}$ rRNA gene of $R$. paucula $\mathrm{LMG}$ 3413 (= CIP 62.31; accession no. AF085226), a close relative (82\% DNA reassociation) of $R$. paucula CDC E6793' ${ }^{\mathrm{T}}$ (Table 2).

The 16S rDNA sequence determined in the present study for $R$. basilensis DSM $11853^{\mathrm{T}}$ (= LMG $18990^{\mathrm{T}}$ $=\mathrm{LMG} 19474^{\mathrm{T}}=\mathrm{RK}^{\mathrm{T}}$; accession no. AF 312022 ) differed in 30 base positions $(97.9 \%$ sequence similarity) from the sequence that was originally deposited for this strain (accession no. AJ002302).

\section{Cellular fatty acids}

Table 3 shows the average fatty acid profiles for the Ralstonia species examined, which are characterized by large amounts of 16:0 (16.8-25.4\%), 18:1 $1 \omega 7 c$
$(18 \cdot 5-36 \cdot 4 \%)$ and summed feature $3(27 \cdot 8-36 \cdot 6 \%)$ and moderate amounts of 14:0 (2.6-5.0\%) and summed feature $2(7 \cdot 7-15 \cdot 4 \%)$.

Discrimination between the different Ralstonia species is based mainly on percentages of fatty acids present in trace to very low amounts or completely absent. Furthermore, $18: 1 \omega 7 c$ seems to be present in $R$. gilardii LMG $5886^{\mathrm{T}}$ in a significantly higher amount $(36.4 \%)$ than in all other Ralstonia strains examined (13.9-27.9\% ; raw data not shown).

\section{Phenotypic tests}

All strains examined grew at 20,30 and $37^{\circ} \mathrm{C}$ and assimilated D-gluconate, adipate and L-malate; glucose, L-arabinose, D-mannose, D-mannitol and maltose were never assimilated. Indole production from tryptophan and acid formation from glucose were never observed. Enzyme activities detected in all strains examined were alkaline phosphatase, C4 esterase, esterase lipase, leucine arylamidase and acid phosphatase. None of the strains examined showed protease, lipase, trypsin, chymotrypsin, $\alpha$-galactosidase, $\beta$-galactosidase, $\beta$-glucuronidase, $\alpha$-glucosidase, $\beta$-glucosidase, $N$-acetyl- $\beta$-glucosaminidase, $\alpha$-mannosidase or $\alpha$-fucosidase activity. Urease activity and reduction of nitrate were variable. Biochemical features that 
Table 4. Biochemical characters that differentiate between $R$. campinensis, $R$. basilensis, $R$. metallidurans and $R$. eutropha

Characters are scored as: + , positive; $\mathrm{w}$, weak; - , negative.

\begin{tabular}{|lcccc|}
\hline Character & R. campinensis & R. basilensis & R. metallidurans & R. eutropha \\
\hline Nitrate reduction & + & $-*$ & $+^{*}$ & $+\dagger$ \\
Nitrite reduction & - & - & $+^{*}$ & $-\dagger$ \\
Denitrification & - & - & $+^{*}$ & $-\dagger$ \\
Urease (after 48 h) & + & + & - & $-\dagger$ \\
Assimilation of citrate & - & - & - & + \\
Growth at 41 ${ }^{\circ} \mathrm{C}$ & + & $\mathrm{w}$ & + & + \\
Acid phosphatase activity & $+^{*}$ & & & + \\
\hline
\end{tabular}

* One or a few strains showed a different reaction.

$\dagger$ The type strain showed a different reaction.

enable differentiation between the four Ralstonia species associated with industrial polluted soils are given in Table 4.

\section{DISCUSSION}

A variety of metal-resistant bacteria related to $\mathrm{CH} 34$, an R. eutropha-like bacterium (Mergeay et al., 1985), were isolated from various industrial metallurgical biotopes (Table 1; Mergeay, 2000). Most of these isolates were examined by means of amplified rDNA restriction analysis (ARDRA) and can be subdivided into two major clusters (Brim et al., 1999). A first cluster contained six isolates obtained from different locations in Belgium, whereas the second cluster contained all other isolates, reference strains of $R$. paucula and several isolates that were received as 'Pseudomonas oxalaticus'.

\section{R. campinensis sp. nov.}

In the present study, the six isolates from ARDRA cluster I (Brim et al., 1999) and two additional ones formed protein electrophoretic cluster I (Fig. 1). Protein electrophoretic cluster I strains were shown to be a homogeneous DNA-hybridization group (Table 2) and could be differentiated further from strains belonging to other Ralstonia species by growth at $41^{\circ} \mathrm{C}$, urease activity and citrate assimilation. The DNA $\mathrm{G}+\mathrm{C}$ content (Table 2) and phylogenetic analysis (Fig. 3) of isolates from cluster I confirmed the allocation of this taxon to the genus Ralstonia. We therefore propose the name $R$. campinensis sp. nov. to accommodate these eight isolates.

The 16S rDNA sequence of $R$. campinensis $\mathrm{WS}^{\mathrm{T}}$ (AF312020) is nearly identical $(99.9 \%)$ to the $16 \mathrm{~S}$ rDNA sequence of Ralstonia sp. CT14, deposited in the EMBL database under accession no. D88001. It is therefore likely that strain CT14 also belongs to the new species $R$. campinensis, although DNA hybridization data are still necessary for a final assignment at the species level (Stackebrandt \& Goebel, 1994).

\section{Differentiation between $R$. basilensis, $R$. paucula and $R$. metallidurans sp. nov.}

In the study of Brim et al. (1999), the majority of metal-resistant bacteria formed a single ARDRA cluster, including the reference strains of $R$. paucula. In the present study, these isolates were distributed over five protein electrophoretic clusters (II-VI), while the type strain of $R$. paucula occupied a clearly distinct position (Fig. 1). Cluster II was composed of six metalresistant strains in addition to the type strain of $R$. basilensis, an organism that was described quite recently (Steinle et al., 1998). DNA-DNA hybridizations revealed high DNA-DNA relatedness values between cluster II strains, while low to intermediate values were measured towards reference strains of the other taxa studied (Table 2). Furthermore, strains of cluster II had very similar whole-cell fatty-acid and biochemical profiles. Therefore, we consider all metal-resistant bacteria belonging to protein electrophoretic cluster II as members of $R$. basilensis. The DNA G $+\mathrm{C}$ content of the $R$. basilensis strains examined conformed to that of the genus. The $16 \mathrm{~S}$ rDNA sequence of $R$. basilensis DSM $11853^{\mathrm{T}}$ determined in the present study and of that of a metalresistant isolate (ER121) revealed $99.7 \%$ sequence identity. However, a reproducible difference of 30 bases was observed between our sequence of the $R$. basilensis type strain and the one deposited in EMBL by Steinle et al. (1998). We received a subculture of $R$. basilensis DSM $11853^{\mathrm{T}}$ twice from the Deutsche Sammlung von Mikroorganismen und Zellkulturen (DSMZ) (once as LMG $18990^{\mathrm{T}}$ and once as LMG $19474^{\mathrm{T}}$ ). Since both subcultures yielded identical whole-cell protein profiles, partial 16S rDNA sequences and repetitive element PCR profiles obtained with the REP and BOX primers (data not shown), we suspect sequencing errors in the sequence deposited by Steinle et al. (1998). Alternatively, the 
sequence deposited by Steinle may not correspond to the strain that was deposited at the DSMZ. The results of the biochemical analysis seem to favour the last hypothesis, because $\mathrm{RK} 1^{\mathrm{T}}$ was reported to be arginine dihydrolase- and urease-positive by Steinle et al. (1998), while no such enzyme activities were found for DSM $11853^{\mathrm{T}}$ in our tests.

The 16S rRNA gene of $R$. basilensis DSM $11853^{\mathrm{T}}$ (accession no. AF312022) showed very high sequence similarities (99.7, $99 \cdot 9$ and $99 \cdot 6 \%$ ) to strains Ralstonia sp. BKME-6 (accession no. AJ011503), KN1 (accession no. AB031995) and MBIC 3902 (accession no. AB017488). Polyphasic taxonomic analysis and/or DNA-DNA hybridization data are needed in order to elucidate the exact taxonomic relationship between these isolates and R. basilensis.

The remaining metal-resistant bacteria that clustered together with $R$. basilensis and $R$. paucula strains in the ARDRA analysis (Brim et al., 1999) formed protein electrophoretic clusters IV, V and VI or occupied distinct positions in the dendrogram (strains AB2, AS2, VA1 and VA11). Visual comparison of their protein profiles (Fig. 2) and DNA-DNA hybridizations (Table 2) showed clearly that these strains represent a new species, for which we propose the name $R$. metallidurans sp. nov. $R$. metallidurans can be differentiated from $R$. campinensis, $R$. basilensis and $R$. eutropha by the presence of the fatty acid 16:0 $2 \mathrm{OH}$ and from $R$. campinensis, $R$. basilensis, $R$. eutropha and $R$. paucula by the ability to reduce nitrate to nitrogen. $R$. metallidurans $\mathrm{CH} 34^{\mathrm{T}}$ was included previously in a taxonomy study of $R$. eutropha-like bacteria by Jenni et al. (1988). These authors reported a low DNA-DNA hybridization level between strain $\mathrm{CH} 34^{\mathrm{T}}$ and the $R$. eutropha type strain, which was confirmed in the present study.

\section{Taxonomic status of other $\boldsymbol{R}$. eutropha-like strains}

Strains JMP134 (Pemberton et al., 1979) and ATCC 17707 (Davis et al., 1970) were originally classified as Alcaligenes eutrophus, now $R$. eutropha. As reported already by Jenni et al. (1988), JMP134 shows only low DNA reassociation values $(21 \%)$ with $\mathrm{H} 20(=\mathrm{ATCC}$ 17700), a genuine $R$. eutropha strain (cluster III, Fig. 1). This is in good agreement with our results of whole-cell protein profiles (Fig. 1), where the former strain occupied a distinct position in the dendrogram, clearly different from the protein profiles of the $R$. eutropha strains. The same observation holds for ATCC 17707. Therefore, we consider both isolates as R. eutropha-like organisms until additional taxonomic data are available.

\section{Description of Ralstonia campinensis sp. nov.}

Ralstonia campinensis (cam.pin.en'sis. L. adj. campinensis of the Kempen or Campine, the geographical region of north-east Belgium where the strains were originally isolated).
Cells are short, motile rods $(0.8 \times 1 \cdot 2-1.8 \mu \mathrm{m})$, single, in pairs or in short chains, forming round (sometimes with a slightly scalloped margin), smooth, convex and transparent colonies of about $0.5 \mathrm{~mm}$ diameter after $24 \mathrm{~h}$ of incubation on TSA at $30^{\circ} \mathrm{C}$. Oxidase- and catalase-positive. Grows at $20,30,37$ and $41{ }^{\circ} \mathrm{C}$, but not at $4{ }^{\circ} \mathrm{C}$. Nitrate is reduced, nitrite is not. No indole production from tryptophan. No glucose fermentation. Enzyme activities detected: urease, alkaline phosphatase, esterase (C4), esterase lipase (C8), leucine arylamidase, valine arylamidase, acid phosphatase and naphthol-AS-BI-phosphohydrolase. Enzyme activities not detected: arginine dihydrolase, $\alpha$-glucosidase (except for strain LH104), protease, $\beta$-galactosidase, lipase (C14), cystine arylamidase, trypsin, $\alpha$-chymotrypsin, $\alpha$-galactosidase, $\beta$-glucuronidase, $\beta$-glucosidase, $N$-acetyl- $\beta$-glucosaminidase, $\alpha$-mannosidase and $\alpha$-fucosidase. Assimilates D-gluconate, caprate, adipate, L-malate and phenylacetate. No assimilation of D-glucose, L-arabinose, D-mannose, D-mannitol, $\mathrm{N}$ acetyl D-glucosamine, maltose or citrate. The DNA $\mathrm{G}+\mathrm{C}$ content is $66 \cdot 6-66 \cdot 8 \mathrm{~mol} \%$. Major fatty acid components are 14:0 (5.0\%), 16:0 (24.6\%), 17:0 cyclo $(6 \cdot 1 \%), 18: 0(1 \cdot 5 \%), 18: 1 \omega 7 c(19 \cdot 5 \%), 14: 0$ $2 \mathrm{OH}(2 \cdot 1 \%), 18: 12 \mathrm{OH}(2 \cdot 7 \%)$, summed feature 2 $(8 \cdot 9 \%)$ and summed feature $3(28 \cdot 4 \%)$.

The type strain, WS2 ${ }^{\mathrm{T}}\left(=\mathrm{LMG} 19282^{\mathrm{T}}=\mathrm{CCUG}\right.$ $44526^{\mathrm{T}}$ ), was isolated from a zinc-desertified area in Lommel, Belgium. Its DNA $\mathrm{G}+\mathrm{C}$ content is $66.6 \mathrm{~mol} \%$ and its phenotypic characteristics are as described above for the species. The accession number of its 16S rRNA gene sequence is AF312020.

\section{Description of Ralstonia metallidurans sp. nov.}

Ralstonia metallidurans (me.tal.li.du'rans. L.n. metallum metal; L. pres. part. durans enduring; N.L. part. adj. metallidurans enduring metal, to indicate that these strains are able to survive high heavy-metal concentrations).

Cells are short, motile rods $(0 \cdot 8 \times 1 \cdot 2-2 \cdot 2 \mu \mathrm{m})$, single, in pairs or in short chains, forming round (sometimes with a slightly scalloped margin), smooth, flat, convex or umbonate and transparent colonies of about $0.5 \mathrm{~mm}$ diameter after $24 \mathrm{~h}$ of incubation on TSA at $30^{\circ} \mathrm{C}$. Oxidase- and catalase-positive. Grows at 20, 30 and $37^{\circ} \mathrm{C}$, but no growth detected at 4 or $41^{\circ} \mathrm{C}$. An exception is AS2, which does grow at $41{ }^{\circ} \mathrm{C}$. Nitrate and nitrite are reduced $\left(\mathrm{CH} 34^{\mathrm{T}}\right.$ reduces nitrate, but not nitrite; VA1 and AS2 reduce neither nitrate nor nitrite). No indole production from tryptophan. No glucose fermentation. Enzyme activities detected: alkaline phosphatase, esterase (C4), esterase lipase (C8), leucine arylamidase, valine arylamidase, acid phosphatase and naphthol-AS-BI-phosphohydrolase. Enzyme activities not detected: arginine dihydrolase, urease (AS2 and AS168 show a weak reaction after $48 \mathrm{~h}$ ), $\alpha$-glucosidase, protease, $\beta$-galactosidase, lipase (C14), cystine arylamidase, trypsin, $\alpha$-chymotrypsin, $\alpha$-galactosidase, $\beta$-glucuronidase, $\beta$-glucosidase, $N$ - 
acetyl- $\beta$-glucosaminidase, $\alpha$-mannosidase and $\alpha$ fucosidase. Assimilation of D-gluconate, caprate (except $\mathrm{CH} 34^{\mathrm{T}}$ ), adipate, L-malate and citrate (except $\mathrm{CH} 34^{\mathrm{T}}$ ). Most strains seem to be able to assimilate phenylacetate after $48 \mathrm{~h}$ of incubation [exceptions are AB2 and VA2 (weak assimilation even after $48 \mathrm{~h}$ ) and $\mathrm{CH} 34^{\mathrm{T}}$ (no assimilation)]. No assimilation of $\mathrm{D}$ glucose, L-arabinose, D-mannose, D-mannitol, $\mathrm{N}$ acetyl D-glucosamine or maltose. The DNA G+C content is $63.7-63.9 \mathrm{~mol} \%$. Major fatty acid components are 14:0 $(4.4 \%), 16: 0(20.9 \%), 17: 0$ cyclo $(3.2 \%), 18: 1 \omega 7 c(19.8 \%), 16: 02 \mathrm{OH}(3.3 \%), 18: 1$ $2 \mathrm{OH}(1 \cdot 4 \%)$, summed feature $2(11.3 \%)$ and summed feature $3(34.2 \%)$.

The type strain, $\mathrm{CH} 34^{\mathrm{T}} \quad\left(=\mathrm{LMG} \quad 1195^{\mathrm{T}}=\mathrm{DSM}\right.$ $2839^{\mathrm{T}}$ ), was isolated from wastewater from a zinc factory at Liège, Belgium. Its DNA $\mathrm{G}+\mathrm{C}$ content is $63.7 \mathrm{~mol} \%$ and its phenotypic characteristics are as described above for the species, unless stated otherwise. The accession number of its $16 \mathrm{~S}$ rRNA gene sequence is $\mathrm{Y} 10824$.

\section{Emended description of Ralstonia basilensis Steinle et al. 1998}

Cells are short, motile rods $(0 \cdot 8 \times 1 \cdot 2-2 \cdot 2 \mu \mathrm{m})$, single, in pairs or in short chains, forming round (sometimes with a slightly scalloped margin), smooth, convex and transparent colonies of about $0.5 \mathrm{~mm}$ diameter after $24 \mathrm{~h}$ of incubation on TSA at $30^{\circ} \mathrm{C}$. Oxidase- and catalase-positive. Grows at 4, 20, 30 and $37^{\circ} \mathrm{C}$, but no growth detected at $41{ }^{\circ} \mathrm{C}$. No nitrate or nitrite reduction (except strain SV884, which reduces nitrate but not nitrite). No indole production from tryptophan. No glucose fermentation. Enzyme activities detected: alkaline phosphatase, esterase (C4), esterase lipase (C8), leucine arylamidase, acid phosphatase (weak) and naphthol-AS-BI-phosphohydrolase. Enzyme activities not detected: arginine dihydrolase, urease (ER8 and KS1 give a weak reaction after $48 \mathrm{~h}$ ), $\alpha$-glucosidase, protease, $\beta$-galactosidase, lipase $(\mathrm{C} 14)$, valine arylamidase, cystine arylamidase, trypsin, $\alpha$ chymotrypsin, $\alpha$-galactosidase, $\beta$-glucuronidase, $\beta$ glucosidase, $N$-acetyl- $\beta$-glucosaminidase, $\alpha$-mannosidase and $\alpha$-fucosidase. Assimilation of D-gluconate, caprate, adipate, L-malate, citrate and phenylacetate. No assimilation of D-glucose, L-arabinose, D-mannose, D-mannitol, $N$-acetyl D-glucosamine or maltose. The DNA $\mathrm{G}+\mathrm{C}$ content is $65 \cdot 0-65 \cdot 5 \mathrm{~mol} \%$. Major fatty acid components are 14:0 (4.5\%), 16:0 (20.6\%), 17:0 cyclo $(1.3 \%), 18: 1 \omega 7 c(24.7 \%), 16: 12 \mathrm{OH}(1.8 \%)$, $18: 12 \mathrm{OH}(4 \cdot 8 \%)$, summed feature $2(9 \cdot 0 \%)$ and summed feature $3(32 \cdot 9 \%)$.

The type strain, RK1 $1^{\mathrm{T}} \quad\left(=\mathrm{LMG} 18990^{\mathrm{T}}=\mathrm{LMG}\right.$ $19474^{\mathrm{T}}=$ DSM $11853^{\mathrm{T}}$ ), was isolated from a freshwater pond sediment at Amponville, France, after enrichment in a fixed-bed reactor with 2,6-dichlorophenol as the sole carbon and energy source. Its DNA $\mathrm{G}+\mathrm{C}$ content is $65.0 \mathrm{~mol} \%$ and its phenotypic characteristics are as described above for the species.
The accession number of the 16S rRNA gene sequence of DSM $11853^{\mathrm{T}}$ is AF312022.

\section{ACKNOWLEDGEMENTS}

This work was partially supported by a project grant G.O.A. (1997-2002) from the Ministerie van de Vlaamse Gemeenschap, Bestuur Wetenschappelijk Onderzoek (Belgium) and by the Vlaams Actie Programma Biotechnologie (VLAB-ETC-003). P.D.V. is indebted to F.W.O. Vlaanderen for a position as Research Director. We thank A. Balcaen, R. Coopman, D. Dewettinck, K. Engelbeen, L. Lebbe, K. Vandemeulebroecke and A. Verhelst for technical assistance.

\section{REFERENCES}

Brim, H., Heyndrickx, M., De Vos, P., Wilmotte, A., Springael, D., Schlegel, H. G. \& Mergeay, M. (1999). Amplified rDNA restriction analysis and further genotypic characterisation of metal-resistant soil bacteria and related facultative hydrogenotrophs. Syst Appl Microbiol 22, 258-268.

Coenye, T., Falsen, E., Vancanneyt, M., Hoste, B., Govan, J. R., Kersters, K. \& Vandamme, P. (1999). Classification of Alcaligenes faecalis-like isolates from the environment and human clinical samples as Ralstonia gilardii sp. nov. Int J Syst Bacteriol 49, 405-413.

Collard, J. M., Corbisier, P., Diels, L. \& 7 other authors (1994). Plasmids for heavy metal resistance in Alcaligenes eutrophus CH34: mechanisms and applications. FEMS Microbiol Rev 14, 405-414.

Davis, D. H., Stanier, R. Y., Doudoroff, M. \& Mandel, M. (1970). Taxonomic studies on some gram negative polarly flagellated 'hydrogen bacteria' and related species. Arch Mikrobiol 70, $1-13$.

De Baere, T., Steyaert, S., Wauters, G., De Vos, P., Goris, J., Coenye, T., Suyama, T., Verschraegen, G. \& Vaneechoutte, M. (2001). Classification of Ralstonia pickettii biovar 3/'thomasii' strains (Pickett 1994) and of new isolates related to nosocomial recurrent meningitis as Ralstonia mannitolytica sp. nov. Int $J$ Syst Evol Microbiol 51, 547-558.

De Ley, J., Cattoir, H. \& Reynaerts, A. (1970). The quantitative measurement of DNA hybridization from renaturation rates. Eur J Biochem 12, 133-142.

De Vos, P., Kersters, K., Falsen, E., Pot, B., Gillis, M., Segers, P. \& De Ley, J. (1985). Comamonas Davis and Park 1962 gen. nov., nom. rev. emend., and Comamonas terrigena Hugh $1962 \mathrm{sp}$. nov., nom. rev. Int J Syst Bacteriol 35, 443-453.

Diels, L. \& Mergeay, M. (1990). DNA probe-mediated detection of resistant bacteria from soils highly polluted by heavy metals. Appl Environ Microbiol 56, 1485-1491.

Diels, L., Dong, Q. H., van der Lelie, D., Baeyens, W. \& Mergeay, M. (1995). The $c z c$ operon of Alcaligenes eutrophus $\mathrm{CH} 34$ : from resistance mechanism to the removal of heavy metals. $J$ Ind Microbiol 14, 142-153.

Ezaki, T., Hashimoto, Y. \& Yabuuchi, E. (1989). Fluorometric deoxyribonucleic acid-deoxyribonucleic acid hybridization in microdilution wells as an alternative to membrane filter hybridization in which radioisotopes are used to determine genetic relatedness among bacterial strains. Int J Syst Bacteriol 39, 224-229.

Goris, J., Suzuki, K., De Vos, P., Nakase, T. \& Kersters, K. (1998). Evaluation of a microplate DNA-DNA hybridization method 
compared with the initial renaturation method. Can J Microbiol 44, 1148-1153.

Hayward, A. C. (1991). Biology and epidemiology of bacterial wilt caused by Pseudomonas solanacearum. Annu Rev Phytopathol 29, 65-87.

Jenni, B., Realini, L., Aragno, M. \& Tamer, A. U. (1988). Taxonomy of non $\mathrm{H}_{2}$-lithotrophic, oxalate-oxidizing bacteria related to Alcaligenes eutrophus. Syst Appl Microbiol 10, 126-133.

Liesegang, H., Lemke, K., Siddiqui, R. A. \& Schlegel, H. G. (1993). Characterization of the inducible nickel and cobalt resistance determinant $c n r$ from pMOL28 of Alcaligenes eutrophus CH34. $J$ Bacteriol 175, 767-778.

Logan, N. A., Lebbe, L., Hoste, B. \& 7 other authors (2000). Aerobic endospore-forming bacteria from geothermal environments in northern Victoria Land, Antarctica, and Candlemas Island, South Sandwich archipelago, with the proposal of Bacillus fumarioli sp. nov. Int J Syst Evol Microbiol 50, 1741-1753.

Marmur, J. (1961). A procedure for the isolation of deoxyribonucleic acid from microorganisms. J Mol Biol 3, 208-218.

Mergeay, M. (2000). Bacteria adapted to industrial biotopes: metal-resistant Ralstonia. In Bacterial Stress Responses, pp. 403-414. Edited by G. Storz \& R. Hengge-Aronis. Washington, DC: American Society for Microbiology.

Mergeay, M., Nies, D., Schlegel, H. G., Gerits, J., Charles, P. \& Van Gijsegem, F. (1985). Alcaligenes eutrophus $\mathrm{CH} 34$ is a facultative chemolithotroph with plasmid-bound resistance to heavy metals. J Bacteriol 162, 328-334.

Mesbah, M., Premachandran, U. \& Whitman, W. B. (1989). Precise measurement of the $\mathrm{G}+\mathrm{C}$ content of deoxyribonucleic acid by high-performance liquid chromatography. Int J Syst Bacteriol 39, 159-167.

Nies, D., Mergeay, M., Friedrich, B. \& Schlegel, H. G. (1987). Cloning of plasmid genes encoding resistance to cadmium, zinc, and cobalt in Alcaligenes eutrophus CH34. J Bacteriol 169, 4865-4868.

Pemberton, J. M., Corney, B. \& Don, R. H. (1979). Evolution and spread of pesticide degrading ability among soil microorganisms. In Plasmids of Medical, Environmental and Commercial Importance, pp. 287-299. Edited by K. N. Timmis \& A. Pühler. Amsterdam: Elsevier/North-Holland Biomedical Press.

Pitcher, D. G., Saunders, N. A. \& Owen, R. J. (1989). Rapid extraction of bacterial genomic DNA with guanidium thiocyanate. Lett Appl Microbiol 8, 151-156.

Pot, B., Vandamme, P. \& Kersters, K. (1994). Analysis of electrophoretic whole organism protein fingerprints. In Chemical Methods in Prokaryotic Systematics, pp. 493-521. Edited by M. Goodfellow \& A. G. O'Donnell. Chichester: Wiley.

Ralston, E., Palleroni, N. J. \& Doudoroff, M. (1973). Pseudomonas pickettii, a new species of clinical origin related to Pseudomonas solanacearum. Int J Syst Bacteriol 23, 15-19.

Şahin, N., Işik, K., Tamer, A. Ü. \& Goodfellow, M. (2000). Taxonomic position of 'Pseudomonas oxalaticus' strain $\mathrm{Ox} 1^{\mathrm{T}}$ $\left(\right.$ DSM $\left.1105^{\mathrm{T}}\right)($ Khambata and Bhat, 1953) and its description in the genus Ralstonia as Ralstonia oxalatica comb. nov. Syst Appl Microbiol 23, 206-209.

Schmidt, T. \& Schlegel, H. G. (1994). Combined nickel-cobaltcadmium resistance encoded by the ncc locus of Alcaligenes xylosoxidans 31A. J Bacteriol 176, 7045-7054.

Schmidt, T., Stoppel, R. D. \& Schlegel, H. G. (1991). High-level nickel resistance in Alcaligenes xylosoxydans $31 \mathrm{~A}$ and Alcaligenes eutrophus KT02. Appl Environ Microbiol 57, 3301-3309.

Siddiqui, R. A., Benthin, K. \& Schlegel, H. G. (1989). Cloning of pMOL28-encoded nickel resistance genes and expression of the genes in Alcaligenes eutrophus and Pseudomonas spp. J Bacteriol 171, 5071-5078.

Stackebrandt, E. \& Goebel, B. M. (1994). Taxonomic note: a place for DNA-DNA reassociation and $16 \mathrm{~S}$ rRNA sequence analysis in the present species definition in bacteriology. Int $J$ Syst Bacteriol 44, 846-849.

Steinle, P., Stucki, G., Stettler, R. \& Hanselmann, K. W. (1998). Aerobic mineralization of 2,6-dichlorophenol by Ralstonia sp. strain RK1. Appl Environ Microbiol 64, 2566-2571.

Vandamme, P., Vancanneyt, M., Pot, B. \& 10 other authors (1992). Polyphasic taxonomic study of the emended genus Arcobacter with Arcobacter butzleri comb. nov. and Arcobacter skirrowii sp. nov., an aerotolerant bacterium isolated from veterinary specimens. Int $J$ Syst Bacteriol 42, 344-356.

Vandamme, P., Goris, J., Coenye, T., Hoste, B., Janssens, D., Kersters, K., De Vos, P. \& Falsen, E. (1999). Assignment of Centers for Disease Control group IVc-2 to the genus Ralstonia as Ralstonia paucula sp. nov. Int J Syst Bacteriol 49, 663-669.

Vauterin, L. \& Vauterin, P. (1992). Computer-aided objective comparison of electrophoresis patterns for grouping and identification of microorganisms. Eur Microbiol 1, 37-41.

Vauterin, L., Yang, P., Hoste, B., Vancanneyt, M., Civerolo, E. L., Swings, J. \& Kersters, K. (1991). Differentiation of Xanthomonas campestris pv. citri strains by sodium dodecyl sulfatepolyacrylamide gel electrophoresis of proteins, fatty acid analysis, and DNA-DNA hybridization. Int J Syst Bacteriol 41, 535-542. 